\title{
Moderating Effects of Subordinates' Competency Level on Leadership and Organization Citizenship Behavior
}

\author{
Kim Lian Lee (Corresponding author) \\ Department of Business Policy and Strategy, Faculty of Business \& Accountancy \\ University of Malaya, 50603 Kuala Lumpur, Malaysia \\ E-mail: kllee1970@yahoo.com
}

Abdul Latif Salleh

College of Business Administration, Prince Sultan University

P.O. Box 66833, Riyadh 11586, Kingdom of Saudi Arabia

Fax: 966-1-454-8317 E-mail: latif52@gmail.com

\begin{abstract}
This paper seeks to examine the relationship between leadership styles and organization citizenship behavior within Malaysian companies. The main motivation for the study is to find out how a superior can achieve a greater understanding of the appropriateness of certain leadership styles when dealing with different subordinates' competency level. Although there have been several studies that explored the relationship between leadership styles and citizenship behavior, hitherto there has yet a study carried out to examine the moderating effect of subordinates' competency level on such relationship. Based on the literature review the moderating effect of subordinates' competency level is explored in order to develop the proposed framework of the study. Based on the framework, propositions linking leadership styles, subordinates' competency level and organizational citizenship behavior are developed.
\end{abstract}

Keywords: Leadership, Competence, Organizational Citizenship Behavior

\section{Introduction and Objective of the Study}

The objective of this study is to examine the effects of leadership styles on subordinates' organizational citizenship behavior. A moderating variable - subordinates' competence level - is investigated to find any moderating effects on organizational citizenship behavior when subjected to different leadership styles. This study purports to examine the relationship between these variables in the Malaysian settings. The main motivation for the study is to find out how a superior can achieve a greater understanding of the appropriateness of certain leadership styles when dealing with different subordinates' competency level. While such a relationship has been examined before, there has yet been a study that investigated the role of subordinates' competence level as a moderator.

The findings of this study should shed some light on how superiors could better achieve their objectives of maintaining positive organizational citizenship behavior among their subordinates. This research should be particularly interesting as it is to be conducted in the Malaysian setting of diverse social and organizational cultures. It should provide a glimpse of how Malaysian "organizational men" respond to different leadership styles as social behavior is normally entrenched and "given" in a particular society. The research is also important in that it addresses the vexing question confronting our industrial society: how do we enrich the skills of our managers so that they can act with greater proficiency given that their contributions are derived through people and from their dealing with people and especially their subordinates. One way of looking into this issue is from the "leadership" perspective of interpersonal interactions that occur across organizational levels as characterized by the phrase "superior-subordinate relationships".

Our interest in the issue of interpersonal relationships is driven by our conviction that sound superior-subordinate relationship is crucial to organizational success; and furthermore it is consistent with the humanistic and cooperative work environment sought by contemporary managers. Positive interpersonal relationship at workplace should enhance positive organizational citizenship behavior (OCB) among the employees. Subordinates with high levels of OCB are more likely to be committed to the organization (William \& Anderson, 1991; Smith, Organ \& Near, 1983). Therefore, it is worthwhile for the superior to be aware of the existing leadership style in work situations and how it promotes 
subordinates' OCB. Negative outcome may lead to organizational dysfunction such as decline in work performances, absenteeism and high turnover (Lamude, 1994; Motowidlo, 2003). According to Graham (1988) and Podsakoff, MacKenzie, Moorman and Fetter (1990) superior's leadership and subordinates' OCB are inter-related. Inappropriate leadership styles may trigger negative consequences, which might further increase the sensitivity and susceptibility to misunderstanding, which in turn decreases the subordinates' OCB. Thus, prevention of subordinates' negative outcome is important vis-a-vis different leadership styles. The mismatch might precipitate an unending and potentially disruptive vicious cycle that many organizational leaders are wont to avoid and therefore the need to address their styles and the attendant consequences more rigorously.

\subsection{Research Questions}

The major research question is to find out the leadership styles employed by superiors in the Malaysian companies and how these styles affect subordinates. This research should also provide insight about the appropriateness and effectiveness of each style as it pertains to specific situation (Yukl, Kim \& Falbe (1996). The key advantage to the examination of these associations is the maximization of organizational outcomes.

Thus, this study seeks to answer the following research questions:

- Are there any significant differences in subordinates' organizational citizenship behavior when subjected to different leadership styles?

- Can subordinates' competence level moderate the relationship between leadership style and organizational citizenship behavior?

\section{Theoretical Framework and Literature Review}

This section attempts to provide the theoretical foundation for the study. A review of the literature is undertaken to define and discuss interactions among the three variables - leadership styles, OCB and subordinates' competence levels (see Note 1).

\subsection{Leadership Styles}

Past researches have extensively studied transactional leadership as the core component of effective leadership behavior in organizations. This was prior to the introduction of transformational leadership theory into the literature (Bass, 1985; Burns, 1978; House, 1977). Transactional leadership is based on exchange relationship where subordinates agreed with, accepted, or complied with the superior in exchange for rewards, resources or the avoidance of disciplinary action (Podsakoff, Todor \& Skov, 1982; Podsakoff, MacKenzie, Moorman \& Fetter, 1990).

More recently, much empirical work has focused on transformational leadership, in particular on the extent to which transformational leadership augments the effect of transactional leadership in explaining various outcomes such as leader effectiveness (Hater \& Bass, 1988), subordinate satisfaction (Seltzer \& Bass, 1990) and subordinate effort (Bass, 1985). These earlier studies are of particular relevant for this proposed research as the extant literature suggests that (1) transactional and transformational leaders employ different kinds of influence strategies to obtain follower conformity, and (2) transactional and transformational leaders elicit different patterns of follower conformity (Kelman, 1958; Howell, 1988; Tichy \& Devanna, 1986).

This emergent genre of leadership study advocates that transformational leaders can motivate followers to perform beyond the normal call of duty. Additionally, transformational leadership finds considerable empirical support where such leaders have been found to have produced leadership effects such as high level of follower motivation, satisfaction, and commitment (Reimers \& Barbuto, 2002; Deluga, 1988; Lok \& Crawford).

\subsection{Organizational Citizenship Behavior (OCB)}

The construct of OCB was introduced by Bateman and Organ (1983) by drawing upon the concept of super role behaviors as presented by Katz and Kahn (1966). Examples of employees OCB include: accepting extra duties and responsibilities at work, working overtime when needed, and helping subordinates with their work (Masterson, Lewis, Goldman \& Taylor, 1996; Organ, 1988). Determining why individuals engage in OCB has occupied a substantial amount of research attention in both organizational behavior and social psychology (Brief \& Motowidlo, 1986; McNeely \& Meglino, 1994). Most research on OCB has focused on individual antecedents. For example, past researches have suggested that there is a relationship between OCB and a host of outcomes, such as satisfaction (Bateman \& Organ, 1983); commitment (O'Reilly \& Chatman, 1986); perceptions of fairness (Folger, 1993; Martin \& Bies, 1991; Moorman, Rohit \& Zaltman, 1993; Tepper \& Taylor, 2003); and perceptions of pay equity (Organ, 1988).

\subsection{Subordinate's Competence}

According to Boyatzis (1982) "competency" can be defined as "an underlying characteristic of an individual which is causally related to effective or superior performance." A related perspective here is the notion that competencies are related to the willingness and ability of the employee to use his/her capacities in specific situations (Spencer, 1983). 
Competencies are factors that contribute to the high levels of individual performance, and hence, organizational effectiveness (Armstrong, 1999). McClelland (1973) who saw competencies as a component of performance associated them with important life outcomes and as an alternative to the traditional trait and intelligence approaches to predicting human performance. Competencies used in this way refer to broad psychological or behavioral attributes that are related to successful outcomes, be it on the job or in life in general.

\section{Hypothesized Relationships}

\subsection{Leadership Styles and $O C B$}

Graham (1988) suggested that the most important effects of transformational leadership behavior should be on extra-role behaviors that exceed the requirements of in-role expectations. These extra role behaviors are best articulated by the OCB construct (Organ, 1988; Deluga, 1995; Organ \& Konovsky, 1989; Podsakoff et al. 1990. OCB is a behavior, largely discretionary and seldom included in formal job description. This behavior is said to be able to promote efficient and effective functioning of the organization (Organ, 1988). Transformational leaders motivate followers by getting them to internalize and prioritize a larger collective cause over individual interests. Individuals who are intrinsically motivated to fulfill a collective vision without expecting immediate personal and tangible gains may be inclined to contribute toward achieving the shared workplace goal in ways that their roles do not prescribe. These individuals make these contributions because in performing these acts their senses of self-worth and self-concepts are enhanced. Individuals for whom this link between the interests of self and others has not been established are less likely to make these largely discretionary, non-tangibly rewarded contributions.

Results of past researches show that transformational leadership has been consistently linked to followers' higher level of OCB (Bass, 1985; Organ, 1988; Podsakoff et al., 1990; Howell \& Avolio, 1993; Lowe, Kroeck \& Sivasubramaniam, 1996; Geyer \& Steyrer, 1998; Wang, Law, Hackett, Wang, Chen, 2005; Schlechter \& Engelbrecht, 2006; Boerner, Eisenbeiss, Griesser, 2007). On the other hand, the relationship between transactional leadership and OCB has been less empirically examined. In any case, Graham (1988) suggests that the instrumental compliance to obtain rewards required by transactional leadership may suggest a reduction in OCB when working for a transactional leader. Bass and Avolio (1990) lend support to this view for they found that transactional leadership is negatively associated with followers' level of OBC. Thus, it may be hypothesized:

Hypothesis 1a: Transformational leadership style is positively correlated with OCB.

Hypothesis $1 \mathrm{~b}$ : Transactional leadership style is negatively correlated with OCB

\subsection{Leadership Styles and Subordinates' Competence}

Past research done by Dockery and Steiner (1990) concluded that subordinates' ability affects the leadership style. According to these authors, the rationale is that a transformational leader would want to give more latitude and support to subordinates who have high ability and perform well. The finding implies that superior's exercise of leadership styles can be affected by subordinates' competence level. It can be conjectured then that if the subordinates' competence level is high, the superior may exercise transformational leadership, and that when subordinates' competency level is low, the superior may be expected to adopt transactional leadership. One possible explanation is that a superior who lacks confidence in his/her own capabilities may feel threatened by highly competent subordinates. Thus, the following hypotheses are advanced:

Hypothesis 2a: Transformational leadership style is positively correlated with subordinates' competency level.

Hypothesis $2 \mathrm{~b}$ : Transactional leadership style is negatively correlated with subordinate competency level.

\subsection{Subordinate Competence and $O C B$}

The concept of competency refers to applied knowledge and skills, performance and the behaviors required to complete a task very well (Armstrong \& Baron, 1995). With regard to subordinate competency the concept implies that subordinates must be able to perform their role effectively (Armstrong, 2000). OCB is an individual behavior that is discretionary, not directly or explicitly recognized by the formal reward system (Organ, 1988), and this behavior is a matter of personal choice. It has been proposed that OCB links performance and job satisfaction in a meaningful way (Organ, 1988; Moorman, 1991). This is well argued by Boyatzis (1982) who placed the concept of competency firmly in the context of effective performance from the outset. He further enhanced the inherent conceptual importance of higher levels of performance by defining competencies as those characteristics that differentiate superior performance from average and poor performance.

Another study by Tremblay (2000) concluded that the perception of a high level of autonomy and influence on the work and the possibility of using competencies have a strong independent positive influence on the mobilization of discretionary behaviors. Complimentary to this, Dio's (1979) research established that subordinates' competency leads to a higher quality of decision and greater achievement and efficiency. In the same vein, Garavan and McGuire (2001) add that competencies can be liberating and empowering, arguing that if employees are provided with a broad degree of 
self-control and self-regulation, they will work towards the fulfillment of organizational objectives. In addition, Dennison (1984) argues that once employees are empowered, they will psychologically perceive meaningfulness, competence, self-determination and impact, which will lead to organizational effectiveness (Lee \& Koh, 2001). These types of competencies are those possessed by knowledge workers, who are increasingly being regarded as the critical resource of the firm (Drucker, 1993). Thus, this study proposes the following related hypotheses:

Hypothesis 3a: Subordinates' competency level is positively associated with OCB.

\subsection{Leadership Style, Subordinates' Competence and OCB}

A more recent study by Pillai et al. (1999) examined the relationship between transformational and transactional leadership, procedural justice and distributive justice, trust in organizational obligation, OCB, and satisfaction from work. He found that an indirect relationship exists between transformational leadership and OCB. In another study, MacKenzie et al. (2001) examined the effect of transformational and transactional leadership on marketing personnel's performance at an insurance company. Their study suggests that transformational leadership has higher influence on performance than has transactional leadership. This finding supports the assumption that the transformational leadership, as compared to transactional leadership style, has a stronger relationship with in role performance and with OCB.

Locke and Schweiger (1979) and Locke et al. (1980) studied group member knowledge and competence in the context of participative decision making (PDM) and performance. Based on their studies, they have come to view competence as a potential moderator variable. Their position would be strengthened if it could be shown that participation enhances the performance of more competent employees but fails to accentuate the performance of less competent personnel. There is an alternative view of the influence of competence on this relation: Supervisors may permit their more competent (and more productive) employees to participate in decisions that affect them. In this scenario, competence (and performance) would determine the level of PDM for each subordinate. Thus, the following hypotheses are advanced.

Hypothesis 4a: Transformational leadership style is positively correlated with OCB. This relationship is moderated by the subordinates' competency level.

\section{Methodology and Research Design}

\subsection{Sampling Design}

The data is to be obtained through survey questionnaire. This method is chosen because it provides certain advantages such as convenience, accessibility and minimal costs. The sampling population will be generated from the master list of factories registered with the Federation of Malaysian Manufacturers (FMM). We will only include manufacturing companies with the number of employees greater than 35 in our sample; this limitation in size is imposed to reflect our belief that a more formalized structure and system of supervision are likely to exist and functioning in firms of certain size. The sample size will be set to 350 respondents comprising executives, managers and professionals in Malaysian manufacturing companies. As a group they represent the more educated people who are in turn more aware of the types of leadership styles displayed by their superiors. The stratified random sampling procedure will be used in selecting the sample from the larger database.

\subsection{Research Instruments}

Each of the measurements of the relevant constructs is discussed in this section as follows.

\subsubsection{Leadership Styles}

Podsakoff, MacKenzie, Morrman \& Fetter's (1990) Transformational Leadership Behavior Inventory (TLI) will be used to measure the leaders' behaviors in this study. The scale measures six dimensions of transformational leadership which includes articulating a vision, providing an appropriate model, fostering the acceptance of group goals, having high performance expectations, providing individualized support, and providing intellectual stimulation. This scale comprises 14 items relating to transformational leadership. For transactional leadership, it will be measured by a four-item contingent reward behavior scale that assesses the degree to which a leader provides positive feedback, such as recognition, informal rewards and approval, contingent on high performance levels. Contingent punishment will be assessed with three items. Previous research has shown these two scales possess good psychometric properties (Podsakoff, Todor, Grover \& Huber 1984; Podsakoff \& Organ, 1986; Podsakoff, Niehoff, MacKenzie \& Williams, 1993; Podsakoff, MacKenzie \& Bommer, 1996).

\subsubsection{Organizational Citizenship Behavior (OCB)}

OCB scale will be measured using a 7-item scale developed by Smith, Organ and Near (1983). Respondents will be asked to indicate the frequency in which they had engaged in the various citizenship behaviours. 


\subsubsection{Subordinates' Competence Level}

Wagner and Morse's (1975) self-reported measure of individual sense of competence will be used to measure the employee's task competence in lieu of a more direct measure of competence level. Thirteen items are extracted from their larger pool of items for use based upon their factor loadings as reported in Wagner and Morse (1975). A sample item states, "I honestly believe I have all the skills necessary to perform this task well." All items are scaled on 7-point agree-disagree rating scales. Evidence pertaining to the reliability and predictive validity of this measure is located in several sources (Morse, 1976; Tharenou \& Harker, 1984; Wagner \& Morse, 1975).

\subsection{Data Analysis Procedure}

The statistical analysis to be employed in this study will include the correlation analysis, moderated regression analysis, and analysis of variance (ANOVA).

\section{Conclusion}

This study is motivated to find out how a superior can achieve a greater understanding of the appropriateness of certain leadership styles when dealing with different subordinates' competency level. Evidences from past researches suggest that when the superior has a choice in selecting leadership styles, he/she would be more inclined toward the transformational style, rather than transactional leadership, in order to achieve greater subordinates' OCB. It has also been suggested that, it is important that the superior must adopt the appropriate leadership styles to manage their subordinates in order for them to perform beyond their call of duties. The moderating effect of subordinates' competence level will also be investigated and it is expected to shed light on how this variable strengthen or weaken the interaction between leadership styles and OCB. In an attempt to solicit subordinate super-ordinate effort in the organization, OCB is included as an outcome variable of this study. Correlation should exist to highlight the relevant leadership style in promoting subordinates' OCB in the organization.

\section{References}

Armstrong, M. \& Baron, A. (1995). The Job Evaluation Handbook. Institute of Personnel Development, London.

Bass, B. M. (1985). Leadership and Performance Beyond Expectations. Free Press, New York.

Bass, B. M. (1990). From transactional to transformational leadership: Learning to share the vision. Organizational Dynamics, 18(3), 19-6.

Bass, B. M. \& Avolio, B. J. (1990). Transformational leadership: A response to critiques. In M.M Chimers \& R. Ayman (Eds.), Leadership Theory and Research: Perspectives and Directives (pp 49-80). New York: Academic Press.

Bateman, T. S. \& Organ, D. W. (1983). Job satisfaction and the good soldier: The relationship between affect and employee "citizenship". Academy of Management Journal, 26, 587-595.

Brief, A. P. \& Motowidlo, S. J. (1986). Prosocial organizational behaviours. Academy of Management Review, 11, 710-725.

Boerner, S, Eisenbesiss, S.A. \& Griesser, D. (2007). Follower behavior and organizational performance: The impact of transformational leaders. Journal of Leadership and Organizational Studies, 13(3): 15-26.

Boyatzis, R.E. (1982). The Competent Manager: A Model for Effective Performance, John Wiley, New York, NY.

Burns, J. M. (1978). Leadership. Harper and Row, New York, NY.

Bycio, P., Hackett, R. D. \& Allen, J. S. (1995). Further assessments of Bass's (1985) conceptualization of transactional and transformational leadership. Journal of Applied Psychology, 80, 468-478.

Deluga, R. J. (1995). The relationship between trust in the supervisor and subordinate organizational citizenship behavior. Military Psychology, 7, 1-16.

Dennison, D. (1984). Bringing corporate culture to the bottom line. Organizational Dynamics, 13, 4-22.

Dio (1979). Participative decision making: a comparative study. Industrial Relations, 18, 295-309.

Dockery, T.M. \& Steiner, D.D. (1990). The role of the initial interaction in Leader-Member Exchange. Group \& Organization Studies, 15(4), 395.

Drucker, P. (1993). Post-capitalist Society, Butterworth-Heinemann, Oxford.

Folger, G. (1993). Justice, motivation, and performance beyond role requirements. Employee Responsibilities and Rights Journal, 6(3), 239-248.

Garavan, T. \& McGuire, D. (2001). Competencies and workplace learning: Some reflections on the rhetoric and the reality. Journal of Workplace Learning, 13(4), 144-63.

Geyer, L. \& Steyrer, J. M. (1998). Transformational leadership and objective performance in banks. Applied 
Psychology: An International Review, 47, 97-420.

Graham, J. (1988). Transformational leadership: Fostering follower autonomy, not automatic followership. In J. Hunt, B. Baglia, H. Dachler \& C. Schriesheim (Eds.), Emerging Leadership Vistas. Lexington Books: Lexington, MA; pp 73-79.

Hater, J. J. \& Bass, B. M. (1988). Superiors' evaluations and subordinates' perceptions of transformational and transactional leadership. Journal of Applied Psychology, 73, 695-702.

Howell, J.M. \& Avolio, B.J. (1993). Transformational leadership, transactional leadership, locus of control, and support for innovation: Key predictors of consolidated-business-unit performance. Journal of Applied Psychology, 78, 891-902.

Katz, D. \& Kahn, R. L. (1966). The Social Psychology of Organizations. New York: Wiley.

Kelman, H. C. (1958). Compliance, identification and internalization: Three processes of opinion change. Journal of Conflict Resolution, 2, 51-60.

Lamude, K. G. (1994). Supervisors' influence tactics for handling managers' resistance. Psychological Reports, 75 , 371-374.

Lee, M. \& Koh, J. (2001). Is empowering really a new concept? Journal of Human Resource Management, 12(4), 684-95.

Locke, E.A, Feren, D.B, Mccaleb, V.M, Shaw, K.N \& Denny, A.T. (1980). The relative effectiveness of four methods of motivating employee performance. In K. Dunchan, M. GruneBerg \& D. Walls (Eds.), Changes in working life (pp. $363-388)$.

Locke, E.A \& Schweigner, D.M. (1979). Participation in decision making: One-more look. In B.M. Staw (Ed.), Research in organization behaviour (pp. 265-339)

Lowe, K. B., Kroeck, K. G. \& Sivasubramaniam, N. (1996). Effectiveness correlates of transformational and transactional leadership: A meta-analytic review of the MLQ literature. Leadership Quarterly, 1 7, 385-425.

Masterson, S. S., Lewis, K., Goldman, B. \& Taylor, M. S. (1996). Integrating justice and social exchange: The differing effects of fair procedures and treatment on work relationships. Academy of Management Journal, 43, 738-748.

McClelland, D.C. (1973). Testing for competence rather than for intelligence. American Psychologist, 28(1), 1-14.

O'Reilly, C. \& Chatman, J. (1986). Organizational commitment and psychological attachment: The effects of compliance, identification, and internalization on prosocial behavior. Journal of Applied Psychology, 71(3), 492-499.

Organ, D. W. (1988). Organizational Citizenship Behavior: The Good Soldier Syndrome. Lexington, MA: Lexington Books.

Organ, D. W. \& Konovsky, M. (1989). Cognitive versus affective determinants of organizational citizenship behavior. Journal of Applied Psychology, 74, 157-164.

Podsakoff, P.M., Mackenzie, S.B. \& Bommer, W.H. (1996). A meta-analysis of the relationships between Kerr and Jermier's substitutes for leadership and employee job attitudes, role perceptions and performance. Journal of Applied Psychology, 81, 380-399.

Podsakoff, P. M., MacKenzie, S. B. Morrman, R. H. \& Fetter, R. (1990). Transformational leader behaviors and their effects on follower's trust in leader satisfaction and organizational citizenship behaviors. Leadership Quarterly, 1, 107-142.

Podsakoff, P. M., Todor, W. D., Grover, R. A. \& Huber, V.L. (1984). Situational moderators of leader reward and punishment behaviors: Fact or fiction? Organizational Behavior and Human Performance, 34(1), 1-63.

Podsakoff, P. M., Todor, W. D. \& Skov, R. (1982). Effects of leader contingent and non contingent reward and punishment behaviours on subordinate performance and satisfaction. Academy of Management Journal, 22 , 810-821.

Schmidt, S. M. \& Kipnis, D. (1984). Manager's pursuit of individual and organizational goals. Human Relations, 37, 781-794.

Schlechter, A.F. \& Engelbrecht, A.S. (2006). The relationship between transformational leadership, meaning and organizational citizenship behavior. Management Dynamics, 15(4), 2-16.

Seltzer, J. \& Bass, B. M. (1990). Transformational leadership: Beyond initiation and consideration. Journal of Management, 16(4), 693-703.

Spencer, L.M. (1983). Soft Skills Competencies. Scottish Council for Research in Education, Edinburgh.

Tharenou, P. \& Harker, P. (1984). Moderating influence of self-esteem on relationships between job complexity, performance, and satisfaction. Journal of Applied Psychology, 69(4), 623-632. 
Tremblay, M. (2000). Organisational and individual determinants of a typical employment: The case of multiple jobholding and self-employment, IQRC, Montreal.

Wagner, F.R. \& Morse, J.J. (1975). A measure of individual sense of competence. Psychological Reports, 36, $451-459$.

Wang, H., Law, K.S., Hackett, R.D., Wang, D. \& Chen, Z.H. (2005). Leader-member exchange as a mediator of the relationship between transformational leadership and followers' performance and organizational citizenship behavior. Academy of Management Journal, 48(3), 420-432.

Williams, L. J. \& Anderson, S. E. (1991). Job satisfaction and organizational commitment as predictors of organizational citizenship and in-role behavior. Journal of Management, 17, 601-617.

Yukl, G. A., Falbe, C. M. \& Youn, J. Y. (1993). Patterns of influence behavior for managers. Group and Organizational Management, 18, 5-28.

\section{Notes}

Note 1. Theoretical model depicting interactions involving leadership style, subordinate competence and OCB.

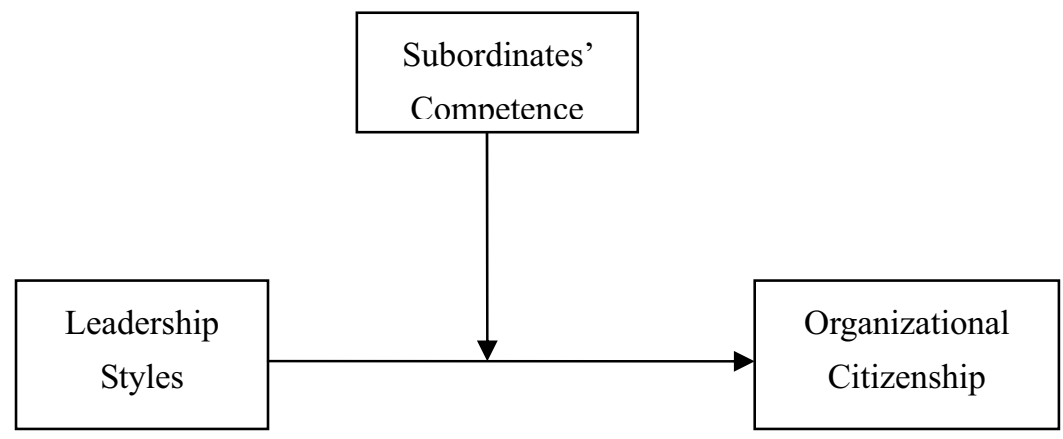

Figure 1. Proposed Model of Leadership Styles and Interactions 